\title{
Meat protein quality of Dormitator latifrons (Pisces: Eleotridae): arguments for use by rural communities
}

\section{Calidad proteica de la carne de Dormitator latifrons (Pisces: Eleotridae): argumentos para su uso en comunidades rurales}

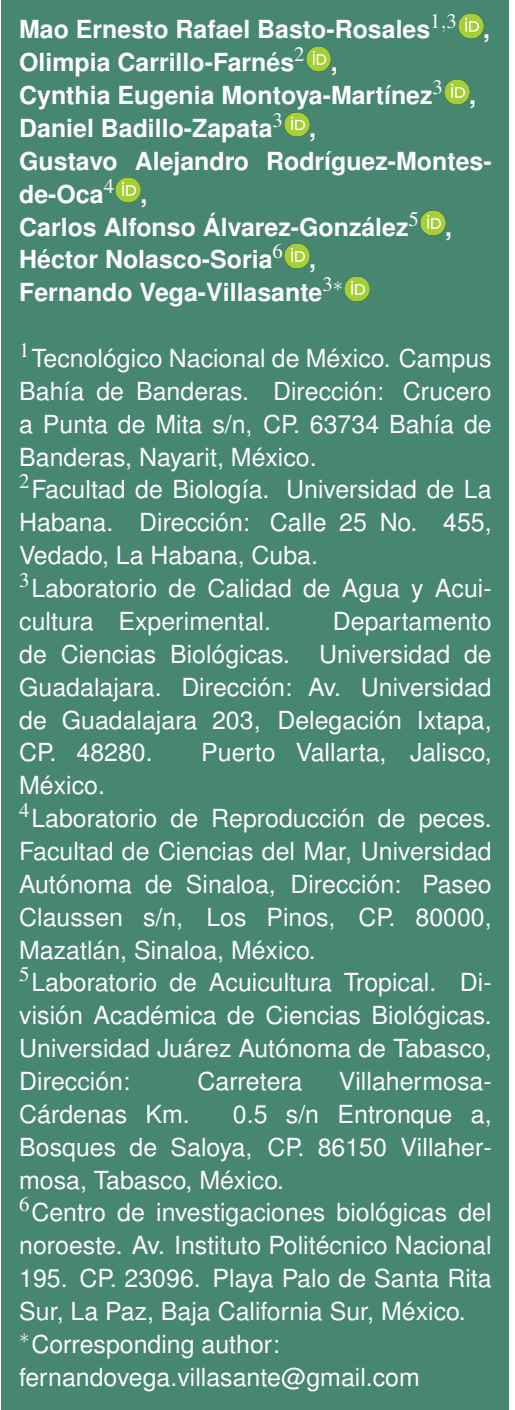

Scientific note

Received: march 08, 2019

Accepted: august 24, 2019

How to cite: Basto-Rosales MER, Carrillo-Farnés
O, Montoya-Martinez CE, Badillo-Zapata D, Rodríguez-
Montes-de-Oca GA, Álvarez-González CA, Nolasco-Soria
H, Vega-VVillasante F (2020) Meat protein quality of Dormi-
tator latifirons (Pisces: Eleotridae): arguments for use by
rural communities. Ecosistemas y Recursos Agropecua-
rios 7(1): e2172. DOI: $10.19136 /$ era.a7n1.2172
ABSTRACT. The objective of this study was to evaluate the quality of meat protein of Dormitator latifrons for humans based on its Protein Digestibility Corrected Amino Acid Score (PDCAAS). Wild and cultured specimens were evaluated for amino acid content using HPLC equipment. The calculation of PDCAAS was performed as follows: milligrams of essential amino acid in $1 \mathrm{~g}$ of test protein per milligram of the same amino acid in $1 \mathrm{~g}$ of reference protein per true digestibility. To evaluate the protein of $D$. latifrons in relation to that of other fish, PDCAAS was calculated from the proteins of eight fish usually used in human nutrition. $D$. latifrons has a good essential amino acid profile, providing the same nutritional quality as those of other fish. Although the meat of wild $D$. latifrons contributes only $73 \%$ of human lysine requirements, it can be complemented with other lysine sources.

Key words: Essential amino acids, human nutrition, limiting amino acid, native fish, muscle protein, low-income communities.

RESUMEN. El objetivo de este estudio fue evaluar la calidad de la proteína de carne de Dormitator latifrons para los seres humanos de acuerdo al cómputo químico de aminoácidos corregido por la digestibilidad de la proteína (PDCAAS). A los músculos de peces silvestres y cultivados se determinó el contenido de aminoácidos utilizando un equipo HPLC. El cálculo de PDCAAS fue: mg de aminoácido esencial en $1 \mathrm{~g}$ de proteína a probar $\mathrm{mg}^{-1}$ del mismo aminoácido en $1 \mathrm{~g}$ de proteína de referencia por digestibilidad verdadera. Se evaluó la proteína de $D$. latifrons en relación con otros peces utilizados en la nutrición humana. $D$. latifrons posee un buen perfil de aminoácidos esenciales que satisface los requerimientos humanos y la misma calidad nutricional que otros peces. Aunque la carne de $D$. latifrons silvestre contribuye con el $73 \%$ de los requerimientos humanos de lisina, se puede complementar con otras fuentes de este aminoácido.

Palabras clave: Aminoácidos esenciales, aminoácido limitante, comunidades pobres, proteína del músculo, nutrición humana, pez nativo. 


\section{INTRODUCTION}

Aquaculture research is continuously seeking new fish species that may have nutritional and commercial value. There is a trend towards increasing the variety of aquatic organisms with culture potential, especially the use of native species (FAO 2010, Saint-Paul 2017). Aquatic foods make a significant contribution to improving dietary intakes and promoting healthy nutrition among most population groups (Toppe et al. 2012). Rural populations living in riparian and coastal areas are some of the poorest communities in the world. These communities not only consume fish but also depend on it for their income and livelihoods (Dey et al. 2017). Rural communities capture small fish for consumption, and the remainder is sold and bought in small quantities. All small fish species are a rich source of animal protein and bioavailable calcium. Some are rich in vitamin A, iron, zinc and essential fatty acids (Thilsted 2012).

Dormitator latifrons, also known as chame, popoyote, puyeque and Pacific fat sleeper (Rodríguez-Montes de Oca et al. 2012), is a fish that lives in tropical and subtropical climates, with a preference for brackish water with temperatures between 21 and $30{ }^{\circ} \mathrm{C}$ (FAO 2010), although it has been found in water temperatures of up to $40{ }^{\circ} \mathrm{C}$ (Ancieta-Calderón y Landa-Cannon 1977). It is distributed from the USA (California) to Peru, inhabiting Pacific coastal waters, lagoons and estuarine systems (Yáñez-Arancibia and Díaz-González 1977). In Central America, it has great commercial potential, and its fishing represents an alternative source of employment (Larumbe-Morán 2002, López-López 2015). Few studies have been conducted to evaluate the nutritional value of this fish. López-Huerta et al. (2018) showed that it has a good fatty-acid composition, especially when the fish are cultivated with adequate diets. However, there are no studies evaluating the biological value of muscle protein.

The biological value of a protein depends mainly on its composition of essential amino acids (EAA) and its availability. In 1989 the FAO/WHO Expert Consultation on Protein Quality Evaluation recommended the use of the Protein Digestibility Corrected Amino Acid Score (PDCAAS) method for evaluating protein quality (FAO 1991). The objective of this study was to evaluate the quality of meat protein of $D$. latifrons for humans based on its PDCAAS with a view to providing arguments for its use by rural Mexican populations.

\section{MATERIALS AND METHODS}

Twenty wild specimens of $D$. latifrons (mean weight of $150 \pm 15 \mathrm{~g}$ ) were collected from the lagoon "El Quelele" in Nayarit, Mexico. A cast net was used to catch the fish. Of 12 total organisms collected (all apparently healthy), 6 were randomly selected and frozen immediately $\left(-25^{\circ} \mathrm{C}\right)$ for later analysis. Another 20 fish with similar weights $(150 \pm 17 \mathrm{~g})$ were obtained from a semi-intensive culture performed at the Laboratorio de Calidad de Agua y Acuicultura Experimental (LACUIC), Puerto Vallarta, Jalisco, Mexico, fed for 4 months with a commercial feed (Purina ${ }^{\circledR}$ ) formulated for the growing phase of tilapia (35\% protein, $8 \%$ lipids). The amino acid (AA) composition of the defatted pooled samples of $D$. latifrons muscle collected from the wild $(n=6)$ and from semi-intensive cultures $(n=6)$, were evaluated for AA content using HPLC equipment with a fluorescence detector (Waters 474 series ${ }^{\circledR}$, Milford).

The amino acid profile was determined using the pooled samples (defatted, freeze-dried and pulverized) according to the technique outlined by Vázquez-Ortiz et al. (1995). The micromethod of Bradford (1976) was used to determine the amount of protein in the defatted muscle samples, using bovine serum albumin as a standard.

The calculation of PDCAAS was performed as follows: milligrams of essential amino acid in $1 \mathrm{~g}$ of test protein $\mathrm{mg}^{-1}$ of the same amino acid in $1 \mathrm{~g}$ of reference protein per true digestibility (Schaafsma 2000). The protein digestibility value used was $94 \%$, considering the fish meat value reported by the FAO (1991). The lowest PDCAAS value is the first amino acid limiting the protein quality of the test protein.

To evaluate the protein quality of $D$. latifrons in relation to that of other fish, PDCAAS was calcu- 
lated from the proteins of eight fish usually used in human nutrition. The EAA contents of the fish protein were obtained from USDA food composition tables: tuna (Thunnu salbacares) USDA code 15127, catfish (Ictalurus punctatus) USDA codes 15234 and 15010, carp (Cyprinus carpio) USDA code 15008, tilapia (Oreochromis sp.) USDA code 15261, rainbow trout (Salmo gairdneri) USDA codes 15240 and 15115, salmon (Salmo salar) USDA codes 15076 and 15236, and bass (Mix of Percichthyidae and Centrarchidae) USDA code 15003.

\section{RESULTS AND DISCUSSION}

This is the first report of the amino acid content of $D$. latifrons muscle protein. Table 1 presents the human requirements of essential amino acids (HREAA) and the EAA profile of $D$. latifrons and other fishes usually used as human food. Evident variations between cultivated and wild fish were observed; nevertheless, all amino acid levels were superior to the HREAA (except lysine in wild $D$. latifrons).

Table 2 shows the PDCAAS of $D$. latifrons compared with fishes traditionally used for human consumption. Muscle of cultivated $D$. latifrons presented an amino acid pattern equivalent to those of the reference protein. Only the PDCAAS of lysine was below one, thus lysine was considered as the first limiting amino acid in wild $D$. latifrons protein. All other evaluated fish showed adequate levels of amino acids with a PDCAAS greater than 1. As the first report of the meat protein quality of $D$. latifrons, this study is a highly important step towards proposing its use as a good quality food for human consumption, especially in Mexico and other developing countries with nutritional problems. Rural populations, the most unprotected in Mexico, only have access to fish meat mostly through artisanal subsistence fisheries (FAO 2005), although many of these consume it infrequently.

Malnutrition in Latin America, especially in children, is a problem that affects most of the countries of the region and is mainly concentrated in indigenous populations (CEPAL 2017). Although Mexico has made substantial progress in reducing child malnutrition, the prevalence remains high, with almost $15 \%$ of this population in chronic malnutrition (Palma 2018). Fish that were introduced to Mexico as an inexpensive source of animal protein, such as tilapia, have already become expensive (Flores-Nava et al. 2016) and are therefore economically out of reach of the poorest people. National scientific and technological projects directed to the research and culture of native species have focused their efforts on species of high added value, in their majority directed to an international market and not to address national demand.

In this scenario, aquaculture should represent an alternative source of fish food, providing protein, essential fatty acids, vitamins and minerals, as well as contributing to food security, the generation of foreign exchange and regional development. However, for Mexico this vision of aquaculture has not fulfilled all these premises, especially those related to improving the nutritional quality of marginalized populations. According to The State of World Fisheries and Aquaculture (FAO 2018), Latin America will see a considerable increase in its total fish consumption: $33 \%$. This is particularly important for the region, since it is currently a net exporter of fish and a large producer of aquaculture but has the lowest per capita consumption worldwide: only $9.8 \mathrm{~kg}$ per year. In 2015, Latin America only consumed 6.2 million tons of fish, less than all the other regions of the world, except for Oceania (FAO 2018).

In Mexico there are freshwater species that have a high productive potential but have been poorly studied, as is the case for $D$. latifrons. However, in other countries such as Ecuador, D. latifrons, it is considered a resource in popular demand, and its production occurs in both fisheries and ponds (using wild offspring) (Schwarz 2007, Arriaga and Martínez 2002). Ecuador has the largest stock of empirical knowledge about this species, as it is a native resource that is part of traditional gastronomy, is one of the most commercialized species and is even exported because its meat is considered exquisite (Delgado et al. 2016). However, and paradoxically, with regard to nutritional value, there is very little published information. López-Huerta et al. (2018) determined the proximal composition and fatty acid profiles of wild and cultivated specimens and observed a good com- 
Table 1. Human requirements for EAA and the EAA content of muscle of $D$. latifrons and other fishes ( $\mathrm{mg} / \mathrm{g}$ protein).

\begin{tabular}{|c|c|c|c|c|c|c|c|c|c|c|c|c|c|}
\hline \multirow{2}{*}{ EAA } & \multirow{2}{*}{$\begin{array}{c}\text { Human } \\
\text { requirements } \\
1-2 \text { years } \\
\text { children }\end{array}$} & \multicolumn{2}{|c|}{$\begin{array}{c}\text { Dormitator } \\
\text { latifrons }\end{array}$} & \multirow{2}{*}{ Tilapia } & \multirow{2}{*}{ Bass } & \multirow{2}{*}{ Carp } & \multicolumn{2}{|c|}{$\begin{array}{c}\text { Rainbow } \\
\text { trout }\end{array}$} & \multicolumn{2}{|c|}{ Catfish } & \multicolumn{2}{|c|}{$\begin{array}{l}\text { Atlantic } \\
\text { salmon }\end{array}$} & \multirow{2}{*}{ Tuna } \\
\hline & & farm & wild & & & & farm & wild & farm & wild & farm & wild & \\
\hline Histidine & 18 & 26 & 32 & 23 & 29 & 29 & 31 & 29 & 22 & 29 & 29 & 27 & 28 \\
\hline Isoleucine & 25 & 39 & 41 & 46 & 46 & 46 & 48 & 46 & 45 & 46 & 46 & 47 & 44 \\
\hline Leucine & 51 & 65 & 72 & 80 & 81 & 81 & 85 & 81 & 76 & 81 & 81 & 79 & 78 \\
\hline Lyisine & 55 & 59 & 43 & 90 & 92 & 92 & 96 & 92 & 91 & 92 & 92 & 92 & 88 \\
\hline Methionine/Cystine & 25 & 35 & 29 & 40 & 40 & 40 & 42 & 40 & 40 & 40 & 40 & 41 & 39 \\
\hline Phenylalanine/Tyrosine & 47 & 77 & 129 & 89 & 73 & 73 & 76 & 73 & 73 & 73 & 73 & 79 & 70 \\
\hline Threonine & 27 & 48 & 60 & 47 & 44 & 44 & 46 & 44 & 45 & 44 & 44 & 42 & 42 \\
\hline Valine & 32 & 43 & 43 & 48 & 51 & 52 & 54 & 52 & 48 & 52 & 52 & 54 & 49 \\
\hline
\end{tabular}

The EAA contents of fish protein were obtained from USDA food composition tables (2018): tuna USDA code 15127, catfish USDA codes 15234 and 15010, carp USDA code 15008, tilapia USDA code 15261, rainbow trout USDA codes 15240 and 15115, salmon USDA codes 15076 and 15236, and bass (Mix of Percichthyidae and Centrarchidae) USDA code 15003. *limiting amino acid.

Table 2. PDCAAS of $D$. latifrons and other fishes used as human food.

\begin{tabular}{|c|c|c|c|c|c|c|c|c|c|c|c|c|}
\hline \multirow{2}{*}{ EAA } & \multicolumn{2}{|c|}{ Dormitator latifrons } & \multirow{2}{*}{ Tilapia } & \multirow{2}{*}{ Bass } & \multirow{2}{*}{ Carp } & \multicolumn{2}{|c|}{ Rainbow trout } & \multicolumn{2}{|c|}{ Catfish } & \multicolumn{2}{|c|}{ Atlantic salmon } & \multirow{2}{*}{ Tuna } \\
\hline & farmed & wild & & & & farmed & wild & farmed & wild & farmed & wild & \\
\hline Histidine & 1.38 & 1.66 & 1.22 & 1.54 & 1.54 & 1.61 & 1.54 & 1.15 & 1.54 & 1.54 & 1.40 & 1.47 \\
\hline Isoleucine & 1.47 & 1.54 & 1.74 & 1.73 & 1.73 & 1.81 & 1.73 & 1.67 & 1.73 & 1.73 & 1.78 & 1.66 \\
\hline Leucine & 1.20 & 1.33 & 1.47 & 1.50 & 1.50 & 1.57 & 1.50 & 1.40 & 1.50 & 1.50 & 1.46 & 1.44 \\
\hline Lyisine & 1.01 & $0.73^{*}$ & 1.54 & 1.57 & 1.57 & 1.64 & 1.57 & 1.56 & 1.57 & 1.57 & 1.57 & 1.50 \\
\hline Methionine/Cystine & 1.33 & 1.08 & 1.52 & 1.52 & 1.52 & 1.58 & 1.52 & 1.50 & 1.52 & 1.52 & 1.56 & 1.45 \\
\hline Phenylalanine /Tyrosine & 1.55 & 2.59 & 1.77 & 1.46 & 1.46 & 1.51 & 1.46 & 1.46 & 1.46 & 1.46 & 1.57 & 1.40 \\
\hline Threonine & 1.69 & 2.10 & 1.65 & 1.53 & 1.53 & 1.60 & 1.53 & 1.57 & 1.53 & 1.53 & 1.47 & 1.46 \\
\hline Valine & 1.26 & 1.26 & 1.42 & 1.51 & 1.51 & 1.58 & 1.51 & 1.42 & 1.51 & 1.51 & 1.59 & 1.45 \\
\hline
\end{tabular}

position of fatty acids of the $\omega 3, \omega 6$ and $\omega 9$ series, and the $\omega 3 / \omega 6$ ratio was higher in wild fish. However, the protein quality of this fish has not been studied so far. In the present work the high quality of its protein was demonstrated by the PDCAAS, a method that measures not only the relationship between the amino acids of the fish and those of the reference protein but also the availability of the protein from digestibility data. The limiting amino acid was lysine, which is often the first limiting factor for many protein sources.

In the present study, the content of essential amino acids of $D$. latifrons and other fish was analysed in relation to human requirements. It was found that $D$. latifrons, despite being a fish not appreciated by rural and coastal populations, has a good essential amino acid profile. Most of the species compared with $D$. latifrons are species with high commercial value (with the exception of carp and tilapia, whose prices are lower); therefore, the possibility of their consumption by rural populations is practically impossible.
One of the few fishing regions for consumption of $D$. latifrons in Mexico is the Laguna de Tres Palos, Guerrero. The price of this fish (whole) is 25 pesos (1.3 USD) on average for a dozen fish that range from 13 to $16 \mathrm{~cm}$ in size, which corresponds to approximately $1 \mathrm{~kg}$. The average price of the fillet is 40 pesos (2.2 USD) $(\mathrm{kg})$. A comparison of these prices with those of other fish consumed in Mexico and analysed for nutritional quality based on their PDCAAS shows that $D$. latifrons, although low in price, provides the same nutritional quality as the other fish included in the analysis. According to the National System of Information and Market Integration (SNIIM) of the Ministry of Economy of Mexico, the fish with the lowest average prices are carp, tilapia and catfish (40.7, 58.5 and 59.7 pesos (2.1, 3.0 and 3.1 USD) $\mathrm{kg}^{-1}$, respectively); tuna, black bass and trout are already priced higher on average (80, 90 and 117.5 pesos (4.2, 4.7 and $6.1 \mathrm{USD}) \mathrm{kg}^{-1}$, respectively). Salmon, which is only sold as a fillet, in Mexico, 
reaches prices of up to 419 pesos (21.8 USD) $\mathrm{kg}^{-1}$. With the exception of lysine, there are no amino acid deficiencies that could make the consumption of this species inadequate for human nutrition. Variations in the chemical composition of fish (including proteins) can be caused by diet, sex, migration and season, among others (Huss 1998) and do not necessarily indicate that, in this case, lysine always remains a limiting amino acid in wild $D$. latifrons throughout the year. However, in cultured fish, the lysine contents are adequate and do not present a limitation. Although the meat of wild fishes contributes only $73 \%$ of human lysine requirements, it is not so serious a limitation that it cannot be complemented with other foods with a high content of this amino acid, such as eggs, beans, soybeans and lentils; most of these foods are usually consumed by low-income communities.
The elimination of malnutrition in marginalized and under-resourced populations in Mexico is a goal that should be obtained as soon as possible. The search for native nutritional sources, high quality and low prices is essential to the provision of alternatives to unprotected communities. Dormitator latifrons is a viable alternative nutritional source of high quality and low cost.

\section{ACKNOWLEDGEMENTS}

The authors thank CONACYT for the scholarship granted to the first author of this manuscript. The authors thank Dr. Julio Morales and C.P. Oscar Morales for providing information on economic aspects of this fish in the Laguna de Tres Palos, Guerrero.

\section{LITERATURE CITED}

Ancieta-Calderón F, Landa-Cannon A (1977) Reseña taxonómica y biológica de los peces cultivados en el área andina incluyendo la costa del Perú. FAO Información Pesca 2: 106-113.

Arriaga L, Martínez J (2003) Plan de ordenamiento de la pesca y acuicultura del Ecuador. Subsecretaria de Recursos Pesqueros. Ministerio de Industrias Comercio y Pesca. Ecuador. 116p.

Bradford MM (1976) Rapid and sensitive method for the quantitation of microgram quantities of protein utilizing the principle of protein-dye binding. Analytical Biochemistry 72: 248-254.

CEPAL (2017) Panorama social de América Latina, 2016. Comisión Económica para América Latina y el Caribe. Santiago, Chile. 284p.

Delgado-Delgado DD, Morán-Caicedo IA, Holguín-Burgos H (2018) Producción y exportación del chame en el Ecuador en el período 2013-2016. Revista Observatorio de la Economía Latinoamericana. Septiembre 2018. https://www.eumed.net/rev/oel/2018/09/produccion-chame-ecuador.html. Data consulted: January 6, 2019.

Dey S, Misra KK, Homechoudhuri S (2017) Reviewing nutritional quality of small freshwater fish species. American Journal of Food and Nutrition 5: 19-27.

FAO (1991) Protein quality evaluation. FAO Food and Nutrition. Paper 51, Rome. 72p.

FAO (2005) Visión general del sector acuícola nacional - México. Departamento de Pesca y Acuicultura de la FAO. http://www.fao.org/fishery/countrysector/naso_mexico/es. Data consulted: January 6, 2019.

FAO (2010) The state of world fisheries and aquaculture 2010 - FAO Fisheries and Aquaculture Department. Food and Agriculture Organization of the United Nations. Rome. 197p.

FAO (2018) The state of world fisheries and aquaculture 2018 - Meeting the sustainable development goals. FAO Fisheries and Aquaculture Department. Food and Agriculture Organization of the United Nations. Rome. $210 p$. 
Flores-Nava A, Villanueva-García BV, Vidal-Martínez VM, Olvera-Novoa MA, Alonso-Marrufo ER, Arreguín-Sánchez F, Poot-López G, Alonso-Alemán M, Maldonado-Repetto A (2016) Diagnóstico de los sectores de la pesca y la acuacultura en el estado de Yucatán. Organización de las Naciones Unidas para la Agricultura y la Alimentación. Gobierno del Estado de Yucatán. Secretaria de Desarrollo Rural. Proyecto UTF/MEX/117. Mérida, Yucatán. 122p.

Huss HH (1998) El pescado fresco: su calidad y cambios de calidad. Manual de capacitación. Programa de capacitación FAO/DANIDA en tecnología pesquera y control de calidad. Colección FAO: Pesca, No. 29. Organización de las Naciones Unidas para la Agricultura y la Alimentación. Roma. 132p.

Larumbe-Morán E (2002) Algunos aspectos biológicos de los Popoyotes (Dormitator latifrons) en cautiverio. Revista Panorama Acuícola 24-25. http://fis.com/panoramacuicola/noticias/noticia\%203.htm. Data consulted: January 6, 2019.

López-Huerta J, Vega-Villasante F, Viana MT, Carrillo-Farnés O, Badillo-Zapata D (2018) First report of nutritional quality of the native fish Dormitator latifrons (Richardson, 1844) (Perciformes: Eleotridae). Latin American Journal of Aquatic Research 46: 849-854.

López-López VV, Rodríguez-Montes de Oca GA, Galavíz MA, Román-Reyes C, Medina-Hernández EA, Dabrowski K, Haws MC (2015) Descripción histológica comparativa del desarrollo del sistema digestivo y visual de larvas de chame Dormitator latifrons (Pisces: Eleotridae). Latin American Journal of Aquatic Research 43: 484-494.

Palma A (2018) Malnutrición en niños y niñas en América Latina y el Caribe. Boletín Desafíos, 21. CEPAL/UNICEF. www.cepal.org/es/enfoques/malnutricion-ninos-ninas-america-latina-caribe?utm_source=CiviCRM\&utm_medium=email\&utm_campaign=Boletin_desafios_21. Data consulted: January 6, 2019.

Rodríguez-Montes de Oca GA, Medina-Hernández EA, Velázquez-Sandoval J, López-López VV, Román-Reyes JC, Dabrowski K, Haws MC (2012) Production of "Chame" (Dormitator latifrons, Pisces: Eleotridae) larvae using GnRHa and LHRHa. Revista Colombiana de Ciencias Pecuarias 25: 422-429.

Saint-Paul U (2017) Native fish species boosting Brazilian's aquaculture development. Acta of Fisheries and Aquatic Resources 5: 1-9.

Schaafsma G (2000) The protein digestibility-corrected amino acid score. Journal of Nutrition 130: 1865S-1867S

Schwarz L (2007) Freshwater fish seed resources in Ecuador. In: Bondad-Reantaso MG (ed) Assessment of freshwater fish seed resources for sustainable aquaculture. FAO Fisheries Technical Paper. No. 501. Food and Agriculture Organization of the United Nations. Rome. pp: 233-240.

Thilsted SH (2012) Improved management, increased culture and consumption of small fish species can improve diets of the rural poor. In: Burlingame B, Dernini S (eds) Sustainable diets and biodiversity: Directions and solutions for policy, research and action. FAO and Bioversity International. Food and Agriculture Organization of the United Nations. Rome. pp: 176-181.

Toppe J, Bondad-Reantaso MG, Hasan MR, Josupeit H, Subasinghe RP, Halwart M, James D (2012) Aquatic biodiversity for sustainable diets: The role of aquatic foods in food and nutrition security. In: Burlingame B, Dernini S (eds) Sustainable diets and biodiversity: Directions and solutions for policy, research and action. FAO and Bioversity International. Food and Agriculture Organization of the United Nations. Rome. pp: 94-101.

Vázquez-Ortiz FA, Caire G, Higuera-Ciapara I, Hernández G (1995) High performance liquid chromatographic determination of free amino acids in shrimp. Journal of Liquid Chromatography 18: 2059-2068. 
Yáñez-Arancibia A, Díaz-González G (1977) Trophic-dynamic ecology of Dormitator latifrons (Richardson) in nine coastal lagoons on the Pacific coast of Mexico. (Pisces: Electridae). Anales del Centro de Ciencias del Mar y Limnología 4 http://biblioweb.tic.unam.mx/cienciasdelmar/centro/1977-1/articulo26.html. Data consulted: January 6, 2019. 
